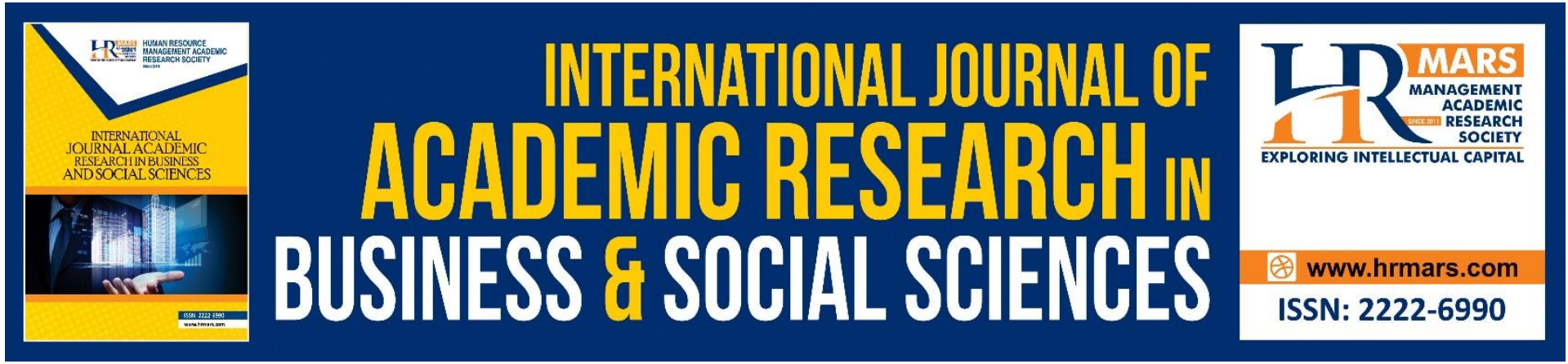

\title{
Tahfiz al-quran in Malaysia: A Study from the View of Model Design and Development Research (DDR)
}

Mohd Shamsul Hakim bin Abd Samad, Mohd Yakub @ Zulkifli bin Mohd Yusoff and Sedek bin Ariffin

To Link this Article: http://dx.doi.org/10.6007/IJARBSS/v11-i8/10967

DOI:10.6007/IJARBSS/v11-i8/10967

Received: 11 June 2021, Revised: 12 July 2021, Accepted: 31 July 2021

Published Online: 24 August 2021

In-Text Citation: (Samad et al., 2021)

To Cite this Article: Samad, M. S. H. bin A., Yusoff, M. Y. @ Z. bin M., \& Ariffin, S. bin. (2021). Tahfiz al-quran in Malaysia: A Study from the View of Model Design and Development Research (DDR). International Journal of Academic Research in Business and Social Sciences, 11(8), 1984-1993.

Copyright: @ 2021 The Author(s)

Published by Human Resource Management Academic Research Society (www.hrmars.com)

This article is published under the Creative Commons Attribution (CC BY 4.0) license. Anyone may reproduce, distribute, translate and create derivative works of this article (for both commercial and non-commercial purposes), subject to full attribution to the original publication and authors. The full terms of this license may be seen at: http://creativecommons.org/licences/by/4.0/legalcode

Vol. 11, No. 8, 2021, Pg. 1984 - 1993

Full Terms \& Conditions of access and use can be found at http://hrmars.com/index.php/pages/detail/publication-ethics 


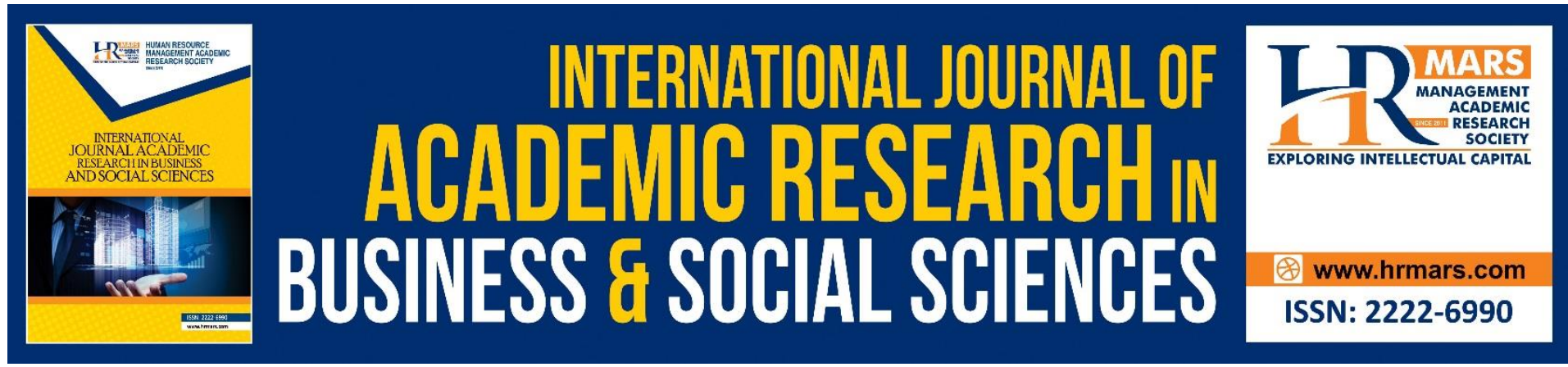

\title{
Tahfiz al-quran in Malaysia: A Study from the View of Model Design and Development Research (DDR)
}

\section{Mohd Shamsul Hakim bin Abd Samad, Dato' Prof. Dr. Mohd Yakub @ Zulkifli bin Mohd Yusoff and Dr Sedek bin Ariffin}

${ }^{1}$ Doctoral Candidate in al-Quran Studies, Department of al-Quran and Hadith, Academy of Islamic Studies, University of Malaya, Kuala Lumpur, ${ }^{2}$ Full Professor, Department of al-Quran and Hadith, Academy of Islamic Studies, University of Malaya, Kuala Lumpur, ${ }^{3}$ Senior Lecturer, Department of al-Quran and Hadith, Academy of Islamic Studies, University of Malaya, Kuala Lumpur.

Email: shamsul@usim.edu.my, zulkifliy@um.edu.my, sedek2001@um.edu.my

\begin{abstract}
Ever since the tahfiz field gains traction among Malaysians especially after the 1990s, various tahfiz methods and models have been introduced either by individuals, organizations or institutions to inculcate the interest of the wider society to memorize the al-Quran as well. Among the popular methods and models of tahfiz al-Quran in Malaysia are Tahfiz al-Baghdadi Method, Tahfiz Ulul Albab Model and the Malaysian Tahfiz Model. Notwithstanding the ultimate goal and purpose of each method and model of tahfiz is to help memorizers of the al-Qur'an in remembering The Book well, it actually requires the correct approach or methodology to ensure each element in the formulation of methods, models or modules of tahfiz al-Quran would be covering all necessary aspects in the process of memorizing the alQuran, as well as via the recognition of experts in the field and the evaluation process by key stakeholders in the field of tahfiz al-Quran. Thus, this paperwork seeks to bring forth research discussion from the perspective of design and development of tahfiz al-Quran model especially in Malaysia as a guidance for making any tahfiz method, model or model that suffices the proper academic methodology research for either of those three components.
\end{abstract}

Keywords: Tahfiz, DDR, Model.

\section{Introduction}

Memorizing the al-Quran is a noble practice encouraged in Islam for those who can do so. Allah SWT has designated a plethora of rewards for this good deed besides merits mentioned by Prophet Muhammad PBUH.

Thus, it is visible among the Muslim community competing to pursue goodness by memorizing the al-Qur'an or at least encouraging their families and others to strive in 
achieving that purpose. This situation has also become a phenomenon in the society particularly after the 90s although this tahfiz stream education has been established in this country since time immemorial. The acceptance of this discipline in the official education stream has begun since the establishment of the Tahfiz al-Quran Study Program at The National Mosque of Malaysia in 1966 as a result of national-level al-Quran Recitation Test in $1960 .{ }^{1}$ It was further augmented with the establishment of several more tahfiz educational institutions under the management of respective state governments such as in Kelantan (1979), Terengganu, Perak, Kedah, Perlis, and Selangor (1980s), Negeri Sembilan, Malacca, Pahang and Sabah (early 1990s) as well as Johore and Penang (1996). Without exception, some tahfiz institutions are also set up by private parties, either under certain individuals or management of certain organizations. ${ }^{2}$

It is a given that the institutions each provides a unique teaching and learning tahfiz curriculum, and this includes the techniques and methods of memorization applied Nonetheless, they share the common supreme goal - to facilitate a person who goes through the particular system to successfully memorize the al-Qur'an.

Memorizing the al-Qur'an is a dignified deed in Islam, but as the dictum goes, "with great power comes great responsibility" for those involved with the process of memorizing the al-Quran. This matter has been explained by al-Imam al-Nawawi in his renowned book alTibyan fi Adab Hamalatil al-Quran (Etiquette with the Quran). ${ }^{3}$

\section{Tahfiz Methods, Models and Modules in Malaysia}

The offer of tahfiz programs under the operation of various tahfiz institutions shows that the diverse tahfiz al-Quran methods have been previously implemented in tahfiz centers. Some of the memorization techniques applied in tahfiz centers are taken from tahfiz al-Quran models overseas such as Pakistan, Turkey, Sudan and so forth. Others are designed and formulated by local experts such as the al-Baghdadi technique, Ulul al-Bab model and more. 4

Some of these tahfiz methods, models and modules have been developed as a result of the experience gone through by instructors or founders of certain institutions whether via trial and error approach, or via the sharing of external instructors. Otherwise, even unspecified methods could be viable in order to give the freedom for memorizers to determine their own style as long as the goal is achievable.

\footnotetext{
${ }^{1}$ Afaf Abdul Ghafor Hameed (2003), Isu Semasa Pengajian Quran dan Sunnah, Kolej Universiti Islam Malaysia, ISBN:9832950171, p. 17.

${ }^{2}$ Ismail, Solahuddin. (2018), Sejarah Perkembangan dan Status Terkini Pengajian Tahfiz Di

Malaysia, Kertas Kerja Muzakarah Institusi Tahfiz Negara Wilayah Utara, Majlis

Perundingan Islam Malaysia (MAPIM), p. 1.

3 Al-Nawãwi, Abu Zakariyã bin Syaraf (1417H/1996M), al-Tibyãn fi Ãdãb Hamalah alQur'ãn, Fourth Edition, Dar Ibn Hazm, Beirut, p. 60.

${ }^{4}$ Mohd Yakub Zulkifli Haji Mohd Yusoff (2016), Sistem Pengajaran dan Pembelajaran Tahfiz Madrasah Tahfiz al-Quran Darul Ta'lim Kampung Tengah, - Memperkasa Darul Quran Ke Arah Memartabat Pendidikan Tahfiz Di Malaysia, Darul Quran JAKIM, ISBN 978-98343708-1-7, p. 10, 35, 61, 76, 116, 154, 161.
} 
The methods have their pros and cons for their implementation in teaching and learning methods. However, if a tahfiz method, or module is developed systematically and methodologically, this can provide more benefits through the following points of view especially for an institution:

1. The ability to develop tahfiz methods, models and modules through the contribution by experts complemented with the views of all stakeholders in the tahfiz field for empowerment.

2. Using consistent methods in the development of a tahfiz method, model and module through the use of research methodology for the development of specific methods, models and modules.

3. The ability to measure the level of effectiveness for the implementation of a method, module and model over time arising from the discipline of documentation and fruitful progress monitoring of any method, model or module.

4. Shaping the discipline and environment of tahfiz education in the established institutions so that the goals can be achieved collectively rather than individually.

Therefore, the authors see the importance of a tahfiz method, model or module to be designed and developed using research methodology design and appropriate formulation of methods, models and modules to meet the needs of tahfiz education, mainly in this modern era that witnesses the proliferation of tahfiz institutions.

\section{Study of Tahfiz Model Design and Development}

The aforementioned advantages for a tahfiz method, model and module to be developed via certain approaches and research methodologies indeed serve as the basis for the launched Study of Tahfiz Model Design and Development. Several tahfiz models and modules have been observed to be formulated using a systematic method with the firm consolidation of specialists and stakeholders.

Among the models seems to be at the forefront in this systematic development is the Tahfiz Ulul Albab Model. This model was first introduced by the Malaysian Ministry of Education as a result of The First Wave of The Malaysian Education Blueprint (PPPM) 20132025. The announcement of its implementation was made on 7 December 2013, by the-then Deputy Prime Minister and Minister of Education, YAB Tan Sri Dato' Haji Muhyiddin b. Haji Mohd Yassin with the name Ulul al-Bab Islamic Education Model and its implementation was expanded nationally starting in 2014.

Initially the idea was sparked by the the-then Minister of Education II, Datuk Seri Idris b. Jusoh through the introduction of this idea at Imtiyaz Secondary School under Yayasan Terengganu. It has been officially enforced at SMK Agama Kuala Lumpur on 16 January 2014 with the first intake of 150 students and 15 teachers. Tahfiz Ulul al-Bab Model (TMUA) is a combination of National Curriculum, Tahfiz Integrated Curriculum (KBT) and Ulul al-Bab Program based on Quranic, encyclopedic and ljtihadic approaches. ${ }^{5}$

\footnotetext{
${ }^{5}$ Siti Nurjanah Mastor Mustafa, Siti Aisyah Johan, Jimaain Safar (2020), Tahap Pencapai Hafazan Murid Tahfiz Model Ulul Albab (TMUA) Sekolah Menengah, Jurnal al-Hikmah, Vol. 12 Issue 2, p. 35-50. UKM. ISSN 1985-6822.
} 
It is also introduced with diverse models according to the suitability of the institution implementing it. There are 3 institutions that adopt this model: the Imtiyaz school, MRSM Ulul Albab, and Sekolah Menengah Agama (Religious Secondary Schools).

The difference between the Tahfiz Ulul Albab Model (TMUA) Imtiyaz and MJSC is that the Imtiyaz School adopts an integrated dual stream system in which the national curriculum is put side-by-side with the al-Quran memorization program. Meanwhile, MJSCs integrates the MJSC (Pure Science) curriculum with the religious stream program, namely memorization of the al-Qur'an (Aminudeen, 2012; Razimi \& Baba, 2013). Although there are contrasts in terms of the curriculum content, all three systems have a common denominator - to produce highly intelligent, multilingual, multidisciplinary al-Quran memorizers with all 30 parts of the holy book firm in their minds.

Likewise, the Tahfiz Malaysia Model was developed by Department of Islamic Development Malaysia (JAKIM) for that purpose. This model was built by a group of experts and researchers at Darul Quran JAKIM, Kuala Kubu Bharu. As a result of the ideas and research by these scholars, this memorization model was introduced in 2018. It has been well documented through a publication entitled Kaedah Hafazan Al-Quran Model Malaysia Teras Panduan Penghafaz Al-Quran (Al-Quran Memorization Method Malaysia Model As A Core Guide for Al-Quran Memorizers). ${ }^{6}$

The focus of this model is to highlight the memorization method of the Malaysian model. However, before this Malaysian model memorization method is taught, some important things related to al-Quran memorization have been informed such as the history of al-Quran memorization, the importance and merits of memorizing the al-Quran, the methods for al-Quran memorization across the world, the study of Quranic principles and alQuran memorization methodology, neurological science in methods and techniques of alQuran Memorization, and also the module al-Quran Memorization: The Practice of Darul Quran, Jakim. Afterwards, the Memorization Method Malaysia Model will be taught to the students.

\section{Methodology}

Among the methodologies of choice for designing and developing tahfiz models is the Model Design and Development Research method proposed by Richey and Klein (2007). The method is similar to other qualitative research methods in terms of approaches used but this one already takes into account the much-needed improvements to meet the needs of practitioners and researchers in their studies. ${ }^{7}$

The purpose of introducing this research approach is to create systematic data-based knowledge derived from practical process and practices seen as parallel with the view of scholars that it is one of the developmental research approaches used. ${ }^{8}$

\footnotetext{
${ }^{6}$ Dr Hj. Nordin bin Ahmad (2019), Kaedah Hafalan Al-Quran Model Malaysia, Darul Quran JAKIM. ISBN 978-983-43708-4-8.

${ }^{7}$ Mohd Riduan bin Mohd Jamil, Nurulrabihah binti Mat Noh (2020), Kepelbagaian Metodologi dalam Penyelidikan Reka Bentuk dan Pembangunan, Cetakan Kedua, Gatscon Sdn. Bhd. Bangi, Selangor. ISBN 978-967-18106, p. 2.

${ }^{8}$ Richey, Klein \& Nelson (2004), Development Research: Studies of Instructional Design and Development. In D. Jonassen (Ed.) Handbook of Research Educational Communication and Technology, New York: Springer, pp. 141-150; Van Dek Akker (1999), Principles and Methods of Development Research in J. Van Den Akker, R. M. Branch, K. Gustafson, N.
} 
In the tahfiz field, this study aims to design and develop a tahfiz al-Quran model for the memorizers and those involved in the system. Principally, this study will use a qualitative method based on the Design and Development Research (DDR) approach that has been developed by Richey and Klein (2007). This qualitative study was chosen because it is thought to be more accurate to know the motives that exist in an institution or organization and observe the real situation that occurs including the surrounding studied by Yin. ${ }^{9}$

This particular research method (DDR) is used as the approach in designing and developing tahfiz models because it is compatible with the design and development approaches in other fields of study, such as learning strategies, program development, model development and product development as agreed by research experts such as Flink and Searns $(1993)^{10}$ as well as Ulrich, Eppinger and Goyal (2011). ${ }^{11}$

In short, the DDR approach in this study will facilitate researchers in planning and developing certain studies. The application of DDR method can also be innovated by diversifying the use of research instruments to suit the combined phases. There are various forms and research results that can be generated from this technique such as models, modules, questionnaires or surveys, frameworks, handbooks, strategy plans and missions depending on the relevant research requirements. Therefore, this design is appropriate for researchers to use this approach because it is relevant to the purpose of this study - to design and develop an accelerated tahfiz al-Quran model for al-Quran memorizers.

As for the design of the study in detail, this study will go through three main phases which will be expounded in the next section.

\section{Objectives}

There are at least three objectives of this study to be conducted:

1. To identify the need to build a tahfiz model based on the perceptions of al-Qur'an memorizers, tahfiz al-Qur'an instructors and the opinions coined by the specialists.

2. To design a model and develop a tahfiz model based on the common practice of alQuran memorization among the practitioners themselves - memorizers and the tahfiz al-Quran instructors - upon taking into account the experts' consensus and views.

3. To evaluate the utilization of the accelerated tahfiz model based on the al-Quran memorization among the memorizers and the tahfiz al-Quran instructors based on the views and consensus among experts.

Each of the targeted objectives will involve phases as determined by Richey and Klein (2007) in this conducted research methodology.

Nieveen \& T. Plomp (Eds), Design Approaches and Tools in Education Training. Dordrecht: Kluwer Academic Publishers, p. 1-14.

${ }^{9}$ Yin, R., (1994). Case study research: Design and methods (2nd ed.). Beverly Hills, CA: Sage Publishing.

${ }^{10}$ Flink, C.A, \& Searns, R.M. (1993). Greenway: A Guide To Planning, Design, And Developtment.

11 Ulrich, K. T., Eppinger, S. D., and Goyal, A. (2011). Product Design And Development, McGraw-Hill, New York. 


\section{Phases}

Richey and Klein stressed that this research method will combine three systematic phases: the requirements phase, the design and development phase, as well as the evaluation and testing phase for the applicability of the intervention. This method is expected to be able to help researchers planning certain studies with the variety of research instruments and methods appropriate to the merged phases. The three phases are:

1) First Phase: Requirement Analysis

2) Second Phase: Design and Development

3) Third Phase: Evaluation and Usability

There are also some other researchers who divide this process into 4 phases in which the second phase of the above arrangement has been further divided into 2 separate phases. Researchers have separated the design process and the development process of a model. This occasion is not a concern in this study since the end result would still be the same considering that it goes through the same process.

It can be further elucidated with the explanation of the following table for a research conducted by this group of researchers:

Table 1

\begin{tabular}{|c|c|}
\hline Phase & Applicable Methods \\
\hline $\begin{array}{l}\text { Phase 1: } \\
\text { Requirement } \\
\text { analysis }\end{array}$ & $\begin{array}{ll}\text { - } & \text { Interview } \\
\text { - } & \text { Survey } \\
\text { - } & \text { Content analysis }\end{array}$ \\
\hline $\begin{array}{l}\text { Phase 2: } \\
\text { Design }\end{array}$ & $\begin{array}{l}\text { - } \quad \text { Delphi Technique } \\
\text { - } \quad \text { Fuzzy Delphi Method } \\
\text { - Interpretive Structural Modelling (ISM) } \\
\text { - } \quad \text { Structural Equation Modelling (SEM) }\end{array}$ \\
\hline $\begin{array}{l}\text { Phase 3: } \\
\text { Development }\end{array}$ & $\begin{array}{l}\text { - } \quad \text { Experts' opinion } \\
\text { - } \quad \text { Interpretive Structural Modelling (ISM) } \\
\text { - } \quad \text { Structural Equation Modelling (SEM) }\end{array}$ \\
\hline $\begin{array}{l}\text { Phase 4: } \\
\text { Evaluation } \\
\text { and usability }\end{array}$ & $\begin{array}{l}\text { - } \text { Interview } \\
\text { - } \text { Survey } \\
\text { - } \text { Quasi-Experiment } \\
\text { - } \text { Pre-test and Post-test } \\
\text { - Effective test/ summative evaluation/ statistical analysis }\end{array}$ \\
\hline
\end{tabular}

\section{Data Collection Method and Details in the Research Phases}

Through a variety of research methods offered for each phase in this approach, researchers have the opportunity to choose one or more of the above methods to fulfill the objectives of answering the problem statements in their study.

In conducting the DDR method on the tahfiz al-Quran model to be developed later on, it will combine several main processes: requirement analysis, context analysis, user analysis,

\footnotetext{
${ }^{12}$ Saedah Siraj, Norlidah Alias, Dorothy Dewitt \& Zaharah Hussin. 2013. Design And Development Research: Emergent Trend In Educational Research. Kuala Lumpur: Pearson Malaysia Sdn Bhd.
} 
content analysis, and most importantly - the evaluation of the products' usability or products made. ${ }^{13}$

First Phase: Requirement analysis. This phase is to identify the prerequisites in developing this study model. It is done through interviews with informants who have determined the minimum number limit to recognize the validity of this model. The main question to be asked revolves around the applicability concerning memorization of the Qur'an in this phase and the possibility for this model to be developed in the form of this research method. The researchers can also use survey methods and content analysis according to the suitability of the study subject.

Second Phase: The main phase in this study - the design and development phase. It is conducted to provide an instrument for the design of this model to be formed, in which researchers will interview experts who are knowledgeable in teaching the al-Qur'an and the field of tahfiz al-Quran itself to gain insight and the methods of tahfiz al-Quran that they have put forth, and the students involved to perceive the perspective of the al-Qur'an memorizers themselves. This interview method is seen as appropriate because the information regarding the teaching of tahfiz al-Quran for al-Quran memorizers will be an added value for the previous literature review based on what has been documented to the findings of the sharing by experts afterwards. Therefore, by interviewing some tahfiz al-Quran teachers, this will contribute to the diversity of methods and knowledge especially in the field of tahfiz al-Quran.

Subsequently, a focus group discussion (FGD) will be conducted to postulate and discuss the instruments listed. This process involves a number of experts from various fields of expertise related to the tahfiz field.

Then, the instruments will be validated by experts in the field of language studies and tahfiz al-Quran before submitted to 12 specialists to be processed using the fuzzy delphi approach. The fuzzy delphi method is used to list the most important elements based on the endorsement of the experts involved before the instruments would be fully developed.

There are other research instruments for this study that can be utilized during this phase such as Interpretive Structural Modeling (ISM) and Structural Equation Modeling (SEM).

Third Phase: The final phase is the model evaluation phase that also uses the Nominal Group Technique (NGT). This technique involves 6 experts. NGT is one of the methods to evaluate the model by using scales and oral evaluation. Data analysis will be measured using this approach. There are also other several options for the instruments as shown in Table 1 above.

\section{Problems and Challenges}

While conducting the study of the design and development of the tahfiz model, there are several problems and challenges in resolving the demands and requirements up to the complete development of a method, model and module of tahfiz.

Among those that can be listed are:

13 ibid. 
1. The equivocacy of the approaches and methodologies used in the study concerned. This may be due to the researcher himself who is still inexperienced in using this form of approach and research methodology.

2. The intricacy of specific data collection for the personal interview sessions with the experts and correspondents involved due to unforeseen circumstances such as the ongoing Covid-19 pandemic.

3. The absence of an official system developed to support the use of each instrument conducted particularly regarding information management for the study and to obtain fast, accurate and punctilious results such as Interpretive Structural Modeling (ISM) and Structural Equation Modeling (SEM).

\section{Suggestions and Solutions}

For the aforementioned problems, several suggestions and solutions are enunciated:

1. Supervisory and monitoring system upon the study overseen by competent experts in the use of research methodology and Model Design and Development Research approach in particular that can accommodate the tahfiz field and Quranic study as well.

2. The use of latest communication technology such as video calls, interface communication platforms and applications, shareable images and recorded videos among others that are capable of replacing conventional methods that rely on physical face-to-face encounters for each of the phases in the study.

3. Develop systems that support the use of each instrument used in the study conducted, mainly from the perspective of research information management and facilitate swift, precise and orderly retrieval of results.

\section{Acknowledgment}

An utmost appreciation and gratitude to Bumiputera Academic Training Scheme (SLAB) and Islamic Science University of Malaysia (USIM) for the scholarship to study at University of Malaya (UM) for the Doctor of Philosophy degree in the field of Al-Quran studies. A heartfelt thanks for Muhammad Nadzif Bin Ramlan, current committee member of Muslim Scholars Association of Malaysia Selangor Chapter (PUMSEL) and a life member of Malaysian Translators Association (MTA) for assisting with the Malay to English translation of this paper.

\section{References}

Akker, V. D. (1999), Principles and Methods of Development Research In J. Van Den Akker, $R$. M. Branch, K. Gustafson, N. Nieveen \& T. Plomp (Eds), Design Approaches and Tools In Education Training. Dordrecht: Kluwer Academic PublishersHameed, A. A. G(2003), Isu Semasa Pengajian Quran dan Sunnah, Kolej Universiti Islam Malaysia, ISBN:9832950171.

Ahmad, N. (2019), Kaedah Hafalan Al-Quran Model Malaysia, Darul Quran JAKIM. ISBN 978983-43708-4-8.

Flink, C. A., \& Searns, R. M. (1993). Greenway: A Guide To Planning, Design, And Developtment.

Ismail, S. (2018). Sejarah Perkembangan dan Status Terkini Pengajian Tahfiz Di Malaysia, Kertas Kerja Muzakarah Institusi Tahfiz Negara Wilayah Utara, Majlis Perundingan Islam Malaysia (MAPIM). 
Mustafa, M. S. N., Johan, S. A., \& Safar, J. (2020),.Tahap Pencapaian Hafazan Murid Tahfiz Model Ulul Albab (TMUA) Sekolah Menengah. Jurnal al-Hikmah, (12) 2. UKM. ISSN 1985-6822.

Mohammad, A. (2012). Program Ulul Albab. Retrieved from http://www.unitpimrsm.net/index.php/berita-fokus/296-program-ulul-albab

Yusoff, M. Y. Z. (2016). Sistem Pengajaran dan Pembelajaran Tahfiz Madrasah Tahfiz al-Quran Darul Ta'lim Kampung Tengah, - Memperkasa Darul Quran Ke Arah Memartabat Pendidikan Tahfiz Di Malaysia, Darul Quran JAKIM, ISBN 978-983-43708-1-7.

Mohamed@Ismail, N. (2012). Program Ulul Albab Sebagai Suatu Proses Transformasi Pendidikan Malaysia. Kajian Kes: Sek. Men. Imtiaz, Terengganu. Paper Pembentangan dalam Bengkel Antarabangsa Pembangunan Berteraskan Islam V(WAPI-5), Medan. Retrieved from: http://www.academia.edu/8050819/PROGRAM_ULUL_ALBAB_SUATU_PROSES_TRA NFORMASI_PENDIDIKAN_Malaysia_KAJIAN_KES_SEKOLAH_MENENGAH_IMTIAZ_TER ENGGANU_1

Jamil, M. R., \& Noh, M. N. (2020). Kepelbagaian Metodologi dalam Penyelidikan Reka Bentuk dan Pembangunan, Cetakan Kedua, Gatscon Sdn. Bhd. Bangi, Selangor. ISBN 978-96718106.

Razimi, M. S. A., \& Baba, S. (2013). Integrating Ulul Albab Education and Science Education in Development Insan Ta'dibi Generation: A Case Study of Mara Junior Science College (MJSC). Prosiding Konferense Pendidikan Antarabangsa WEI, Antalya. Retrieved from http://www.westeastinstitute.com/wp-content/uploads/2013/02/Z-ANT13-236Mohd-Shahril-Bin-Ahmad-Razimi.pdf

Richey, Klein \& Nelson. (2004). Development Research: Studies of Instructional Design and Development. In D. Jonassen (Ed.) Handbook of Research Educational Communication and Technology, New York: Springer.

Siraj, S., Alias, N., Dewitt, D., \& Hussi, Z. (2013). Design And Development Research: Emergent Trend In Educational Research. Kuala Lumpur: Pearson Malaysia Sdn Bhd.

Syaraf, A. Z. (1996). al-Tibyãn fi Ãdãb Hamalah al-Qur'ãn, Fourth Edition, Dar Ibn Hazm, Beirut.

Ulrich, K. T., Eppinger, S. D., and Goyal, A. (2011). Product Design And Development, McGrawHill, New York.

Yin, R. (1994). Case study research: Design and Methods (2nd ed.). Beverly Hills, CA: Sage Publishing. 